RESOLUTION 9

Junior Red Cross

The IXth Inter-American Red Cross Conference

Considering: That the ICRC has implemented the resolutions adopted by the XXIst International Conference of the Red Cross held in Istanbul, by the publication of the textbook "The Red Cross and My Country" as well as of the "Teacher's Manual";

Thanks the ICRC for the Spanish version adopted for Latin America, and

1) Recommends all National Societies and governments to adopt this textbook and to ensure its greatest possible distribution in the schools;

2) Aware of the fact that the resources of the Red Cross are limited, and in view of the need to proceed with the distribution of these publications, deems it necessary that States participate in their financing.

\title{
REGIONAL TRAINING INSTITUTE - EAST AFRICA
}

The first seminar of the Regional Training Institute for East Africa, sponsored by the League of Red Cross Societies, was held at Dar-es-Salaam from 3 to 27 November 1970. Some thirty representatives from seven National Societies of East Africa, Europe and America attended.

The ICRC, which had also been invited to send a representative, delegated to the Tanzania capital the Head of its Press and Information Division and also its two regional delegates for East Africa.

The subjects discussed at this first seminar of the Regional Institute mainly concerned general Red Cross principles, the Geneva Conventions, co-operation with governments, the United 


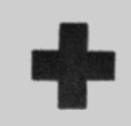

\title{
Ia Cruz Soja Hondureña
}

\section{Presenta este}

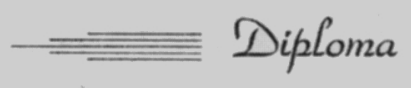

\author{
Al
}

\section{Cometé Internacional de la Cruz Raja}

Como muestra de su agradecimiento por la colaboracion que le ha ptertado en el

desarzollo de su labot en pro del alioio del sufrimiento humano " el entendimiento entre hombres y nacioner.

Dado en la ciudad de Cegucigalpa, Honduras, a ptimeto de Diciembre de 1970 
Nations Organization and its various specialized agencies, youth, relief to refugees and natural disaster victims, health, first-aid, and planning, administrative and information problems. A large part of the time was reserved to the study of African social and cultural structures.

In view of the success of this experiment it was decided to organize shortly a second seminar in Accra, Ghana.

\section{Haiti}

ICRC Delegate-General for Latin America Serge Nessi, in November 1970, went to Port-au-Prince where he visited the National Red Cross Society, development of whose activity is in full swing. We are therefore pleased to give some details.

In its report on achievements during the years 1968 and 1969 , the Haitian Red Cross, which is presided over by Dr. Victor Laroche, gives an account of the medico-social work which it undertakes (vaccinations, $\mathrm{X}$-rays, health education, medical assistance, firstaid and first-aid instruction, ambulance service, mobile first-aid post) and the social welfare service which takes the form of clothing and food donations. In addition, the society's scope has been increased by two new activities, namely:

a) Free six-month courses to 500 students on the theory and practice of pre- and post-natal care. These courses are given at Red Cross headquarters and at several of the capital's hospitals. Students who pass the final examination are awarded a diploma;

b) During " Red Cross Week", which is organized every year by the Society and which, in November 1970, met with considerable success, the Red Cross Blood Transfusion Centre was inaugurated in reconditioned premises consisting of a waiting-room, an examination-room, three transfusion rooms, a laboratory and an office for the director, Dr. Adrien Westerbaut. The 